\title{
Pengaruh Penyuluhan Demam Berdarah Terhadap Perilaku Ibu Rumah Tangga
}

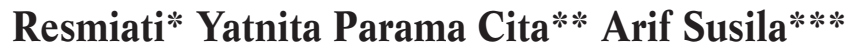

\begin{abstract}
Abstrak
Pada periode tahun 1989-1995, insiden demam berdarah di Indonesia berada pada kisaran 6 -15 per 100.000 penduduk. Pada tahun 1998, dengan angka insidens demam berdarah meningkat tajam menjadi 35,19 per 100.000 penduduk dengan angka kematian (CFR) $2 \%$. Penelitian ini bertujuan mengetahui pengaruh penyuluhan terhadap perilaku. Penelitian ini dilaksanakan di RW 12, Pondok Kelapa, Kecamatan Duren Sawit, Jakarta Timur, terhadap 227 respondent. Penelitian ini menggunakan rancangan penelitian kuasi eksperimen pra-pasca tes dalam satu kelompok (One group pra test and post test design). Pengetahuan dan sikap diukur dengan lembar kuesioner serta tindakan diukur dengan lembar observasi yang sebelumnya telah dilakukan uji coba. Pengukuran dilakukan sebelum dan setelah penyuluhan terhadap 227 responden. Ditemukan penyuluhan tentang DBD berpengaruh secara bermakna terhadap pengetahuan,sikap dan tindakan penduduk (nilai $p=0,000)$. Setelah penyuluhan, nilai rata-rata pengetahuan meningkat dari $(14,4 ; 30 \%)$ menjadi $(18,9$; $88,1 \%)$, nilai sikap meningkat dari $(64,670,9 \%)$ menjadi $(69,6 ; 96,9 \%)$, tindakan dari $(5,1 ; 7,5 \%)$ menjadi $(6,0 ; 17,6 \%)$.
\end{abstract}

Kata kunci : Penyuluhan kesehatan, demam berdarah, ibu rumah tangga

\begin{abstract}
In the period of 1989-1995, the incidence of dengue hemorrhagic fever in Indonesia was within the interval of 6 - 15 per 100.000 population. In 1998 , the incidence increased sharply (35,19 per 100.000 population) with case fatality rate of $2 \%$. The purpose of this research is to evaluate the effect of health counseling on the behaviour of housewives. This research was conducted in 227 respondents in RW 12 of Pondok Kelapa in Duren Sawit district, East Jakarta, to measure respondents' knowledge and practice before and after health counseling. This research used one group quasy experiment design (pre-and-posttest design). The measuring tool is a list of questions and observation check list that had been tested before. The health counseling on dengue fever significantly influences the knowledge and practice of the housewives. This result showed increase of knowledge and practice before and after the counseling. The average knowledge $(14.42 ; 30 \%)$ increased to $18.91 ; 88.1 \%$. The attitude score increased from $64.42 ; 70.9 \%$ to $69.58 ; 96.9 \%$. The practice score increased from $5.11 ; 7.5 \%$ to $5.98 ; 17.6 \%$.

Key words : Health counseling, dengue fever, housewife


Demam Berdarah Dengue atau Dengue Haemorrhagic Fever (DHF) adalah penyakit yang menyerang anak dan dewasa yang ditularkan melalui nyamuk Aedes Aegypti. Gejala utama DHF meliputi demam, nyeri otot dan sendi yang biasanya memburuk setelah dua hari. Uji Tourniquet akan positif dengan atau tanpa ruam disertai beberapa atau semua gejala perdarahan seperti ptekie spontan yang timbul serentak, purpura, epitaksis, hematemesis, melena, trombositopeni, masa perdarahan dan masa protrombin memanjang, hematokrit meningkat dan gangguan maturasi megakariosit. ${ }^{1}$ Penyakit demam berdarah tersebar di wilayah Asia Tenggara, Pasifik Barat dan Karibia. Di wilayah Asia Tenggara penyakit demam berdarah tersebar di India, Indonesia, Myanmar, Srilanka, Thailand dan Malaysia dengan jumlah kasus sebanyak 136.030 dengan jumlah kematian sebanyak 1.037 orang. $^{2}$

Indonesia merupakan wilayah endemis dengan sebaran di seluruh wilayah tanah air. Sejak itu, penyakit tersebut menyebar ke berbagai daerah, sehingga sampai tahun 1980 seluruh provinsi di Indonesia kecuali TimorTimur telah terjangkit penyakit demam berdarah ini. Sejak pertama kali ditemukan jumlah kasus menunjukkan peningkatan baik dalam jumlah maupun luas wilayah. Insiden demam berdarah di Indonesia antara 6 hingga 15 per 100.000 penduduk pada tahun 19891995, pernah meningkat tajam saat kejadian luar biasa pada tahun 1998 dengan angka kejadian (IR) 35,19 per 100.000 penduduk dengan angka kematian (CFR) sebesar $2 \% .^{2}$

Kasus demam berdarah di Indonesia tiga tahun terakhir mengalami peningkatan yang signifikan. Pada tahun 2005 jumlah kasus demam berdarah di Indonesia sebanyak 95.279 dengan jumlah kematian (CFR) sebesar 1,3\%. Pada tahun 2006 insiden demam berdarah mengalami peningkatan sebanyak 114.656 kasus dengan CFR sebesar 1,4\%. Kemudian, pada tahun 2007 insiden demam meningkat tajam sebanyak 157.839 kasus namun, dengan jumlah CFR yang menurun sebesar $1,1 \% .{ }^{3}$

Provinsi yang rawan demam berdarah adalah DKI Jakarta. Terdapat 96 kelurahan di lima kota di Jakarta yang dikategorikan sebagai kawasan merah atau rawan penyakit demam berdarah. Kawasan merah demam berdarah adalah 31 kelurahan di Jakarta Timur, 29 kelurahan di Jakarta Selatan, 15 kelurahan di Jakarta Pusat, 14 kelurahan di Jakarta Utara dan 7 kelurahan di Jakarta Barat. 4

Jakarta Timur merupakan wilayah yang rawan penyebaran demam berdarah. Pada tahun 2005 tercatat 7.203 kasus demam berdarah dengan 22 orang meninggal. Kemudian, pada tahun 2006 tercatat 8.107 kasus dengan 13 orang korban meninggal. Pada tahun berikutnya, jumlah, kasus demam berdarah mengalami peningkatan sebanyak 9.655 kasus dengan 19 orang meninggal dunia.
Sebanyak 10 kecamatan yang ada di Jakarta Timur, Kecamatan Duren Sawit merupakan wilayah rawan penyebaran penyakit demam berdarah. Sepanjang tahun 2007 tercatat 1476 kasus demam berdarah di wilayah tersebut dengan pembagian penyebaran di 7 kelurahan. Kelurahan Klender dengan 243 penderita, Kelurahan Pondok Bambu dengan 185 penderita, Kelurahan Duren Sawit dengan 288 penderita, Kelurahan M. Sari dengan 112 penderita, Kelurahan M. Jaya dengan 133 penderita, Kelurahan Pondok Kopi dengan 170 penderita, dan Kelurahan Pondok Kelapa dengan 345 penderita. ${ }^{4}$

Lingkungan merupakan salah satu faktor yang mempengaruhi penyebaran penyakit demam berdarah. Nyamuk yang merupakan vektor demam berdarah cenderung berkembang biak di air jernih, dingin, dan gelap. Karena itu, tempat perindukan yang harus diwaspadai adalah segala macam tempat penampungan air seperti bak mandi, ember, vas bunga, pot air yang berisi bunga, kaleng bekas dan ban bekas yang dapat tergenang air hujan dan bangunan yang setengah jadi atau terbengkalai. Karena faktor lingkungan di atas, maka dilakukan pencegahan perkembangbiakan dari nyamuk tersebut. Cara pencegahannya antara lain dengan pengasapan dan seminggu sekali menguras tempat penampungan air seperti bak mandi, ember, vas bunga, tempat minum burung dan lainnya. Memberikan bubuk abate 2-3 bulan sekali pada tempat penampungan air yang jarang dikuras, menutup rapat tempat penampungan air, dan mengubur semua barang bekas yang dapat menampung air hujan. Selain strategi di atas, maka usaha untuk mengatasi kasus demam berdarah adalah dengan penyuluhan kesehatan. Penyuluhan kesehatan adalah kegiatan pendidikan yang dilakukan dengan cara penyebaran pesan dan menanamkan keyakinan sehingga masyarakat tidak saja sadar, tahu dan mengerti tetapi juga mau dan bisa melakukan suatu anjuran yang ada hubungannya dengan kesehatan. Penyuluhan kesehatan adalah gabungan berbagai kegiatan dan kesempatan yang berlandaskan prinsipprinsip belajar untuk mencapai suatu keadaan dimana individu, keluarga dan kelompok atau masyarakat secara keseluruhan ingin hidup sehat, tahu bagaimana caranya dan melakukan apa yang bisa dilakukan secara perseorangan maupun kelompok dan meminta pertolongan. ${ }^{5}$

\section{Metode}

Penelitian ini menggunakan rancangan penelitian kuasi eksperimen pra-pasca tes dalam satu kelompok (One group pra test and post test design). ${ }^{6}$ Kriteria inklusi dalam penelitian ini adalah kepala keluarga anggota keluarga dapat membaca dan menulis serta bersedia menjadi responden. Kriteria eksklusi dalam penelitian ini adalah kepala keluarga/anggota keluarga yang tidak bisa membaca dan menulis dan atau tidak bersedia menjadi responden. Setelah penyaringan dilaksanakan, terdapat 30 
responden yang tidak bersedia menjadi responden. Oleh karena itu, peneliti memutuskan untuk menggunakan 227 responden yang akan digunakan dalam penelitian. Penelitian dilaksanakan di RW 012 Kelurahan Pondok Kelapa (RT 001, RT 002, RT 003, RT 006, RT 007, RT 008, RT 009) dan RT 005 untuk uji coba instrumen. Terdapat satu RT yaitu RT 004 yang drop out karena tidak menghadiri penyuluhan kesehatan yang diadakan.

\section{Hasil}

Distribusi statistik deskriptif dan frekuensi pengetahuan, sikap, dan tindakan ibu rumah tangga di RW 012 Kecamatan Duren Sawit Jakarta Timur sebelum dan setelah penyuluhan kesehatan tentang demam berdarah tersaji pada Tabel 1. Efektifitas Penyuluhan Kesehatan Terhadap Sikap Ibu Rumah Tangga di RW 012 Kelurahan Pondok Kelapa Kecamatan Duren Sawit Jakarta Timur tersaji pada Tabel 2.

Rata-rata sikap responden sebelum dilakukan penyuluhan kesehatan tentang demam berdarah adalah 64,621 dengan standar deviasi 6,944. Setelah dilakukan penyuluhan kesehatan tentang demam berdarah, rata-rata sikap responden adalah 69,586 dengan standar deviasi 5,198 . Terlihat nilai mean perbedaan sikap sebelum dan setelah penyuluhan kesehatan adalah - 4,965 dengan standar deviasi 6,659. Hasil uji statistik didapatkan nilai $p=0,000$ maka dapat disimpulkan bahwa penyuluhan kesehatan tentang demam berdarah efektif karena sangat signifikan terhadap sikap ibu rumah tangga di RW 012 Kelurahan Pondok Kelapa Kecamatan Duren Sawit Jakarta Timur. Efektifitas Penyuluhan Kesehatan Terhadap Tindakan Ibu Rumah Tangga di RW 012 Kelurahan Pondok Kelapa Kecamatan Duren Sawit Jakarta Timur tersaji pada Tabel 3.

Rata-rata tindakan responden sebelum dilakukan penyuluhan kesehatan tentang demam berdarah di RW 012 Kelurahan Pondok Kelapa adalah 5,114 dengan standar deviasi 1,880. Setelah dilakukan penyuluhan kesehatan tentang demam berdarah di RW 012 Kelurahan Pondok Kelapa rata-rata tindakan responden adalah 5,907 dengan standar deviasi 1,699. Terlihat nilai mean perbedaan tindakan sebelum dan setelah penyuluhan kesehatan adalah - 0,793 dengan standar deviasi 1,199. Hasil uji statistik didapatkan nilai $\mathrm{p}=0,000$ maka dapat disimpulkan bahwa penyuluhan kesehatan tentang demam berdarah efektif karena sangat signifikan terhadap tindakan ibu rumah tangga di RW 012 Kelurahan Pondok Kelapa Kecamatan Duren Sawit Jakarta Timur.

\section{Pembahasan}

Untuk mengukur efektifitas penyuluhan kesehatan terhadap perilaku digunakan domain perilaku sebagai tolak ukur. Perilaku dapat dibedakan menjadi tiga domain, domain tersebut antara lain adalah pengetahuan, sikap
Tabel 1. Distribusi Nilai Pengetahuan, Sikap, dan Tindakan Ibu Rumah Tangga pada Tes Sebelum dan Sesudah Penyuluhan

\begin{tabular}{llll}
\hline Variabel & Katagori & Tes Sebelum & Tes Sesudah \\
\hline \multirow{2}{*}{ Pengetahuan } & Baik & $68(30 \%)$ & $200(88,1 \%)$ \\
& Cukup & $94(41,4 \%)$ & $10,1(10,1 \%)$ \\
& Kurang & $55(24,2 \%)$ & $4(1,8 \%)$ \\
Sikap & Tidak tahu & $10(4,4 \%)$ & $0(0 \%)$ \\
& Sangat baik & $161(70,9 \%)$ & $220(96,9 \%)$ \\
& Baik & $66(29,1 \%)$ & $7(3,1 \%)$ \\
\multirow{2}{*}{ Tindakan } & Tidak baik & $0(0 \%)$ & $0(0 \%)$ \\
& Sangat tidak baik & $0(0 \%)$ & $0(0 \%)$ \\
& Baik & $17(7,5 \%)$ & $40(17,6 \%)$ \\
& Cukup & $91(40,1 \%)$ & $99(43,6 \%)$ \\
& Kurang & $99(43,6 \%)$ & $82(36,1 \%)$ \\
& Tidak baik & $20(8,8 \%)$ & $6(2,6 \%)$ \\
\hline
\end{tabular}

Tabel 2. Nilai Rata-rata Sikap Ibu Rumah Tangga Sebelum dan Setelah Penyuluhan

\begin{tabular}{llllll}
\hline Variabel & Mean & SD & SE & P value & N \\
\hline Sikap Pre & 64,621 & 6,944 & 0,461 & 0,000 & 227 \\
Sikap Post & 69,586 & 5,198 & 0,345 & & \\
\hline
\end{tabular}

Tabel 3. Nilai Rata-rata Tindakan Ibu Rumah Tangga Sebelum dan Setelah Penyuluhan

\begin{tabular}{lccccc}
\hline Variabel & Mean & SD & SE & P value & N \\
\hline Tindakan Pre & 5,114 & 1,880 & 0,125 & 0,000 & 227 \\
Tindakan Post & 5,907 & 1,699 & 0,113 & & \\
\hline
\end{tabular}

dan tindakan. ${ }^{7}$

\section{Pengetahuan}

Domain perilaku yang pertama adalah pengetahuan. Pengetahuan merupakan hasil dari proses pembelajaran dengan melibatkan indra penglihatan, pendengaran, penciuman dan pengecapan. ${ }^{8}$ Pengetahuan akan memberikan penguatan terhadap individu dalam mengambil keputusan dalam berperilaku. Pada penelitian ini, peneliti menggunakan metode seminar dengan media LCD dan alat peraga berupa leaflet tentang demam berdarah serta dijelaskan oleh pemberi materi/ penyampai pesan, metode tersebut melibatkan indra penglihatan dan pendengaran. Rata-rata pengetahuan sebelum dilakukan penyuluhan kesehatan tentang demam berdarah di RW 012 Kelurahan Pondok Kelapa adalah 14,42 dengan jumlah pengetahuan baik sebanyak 68 responden $(30 \%)$ namun, setelah penyuluhan kesehatan diadakan rata-rata pengetahuan responden meningkat menjadi 18,91 dengan pengetahuan baik sebanyak 200 responden $(88,1 \%)$.

Pengetahuan masyarakat meliputi pengetahuan tentang penyebab demam berdarah, vektor demam 
berdarah serta ciri-cirinya, cara penularan demam berdarah, sasaran demam berdarah, tanda dan gejala demam berdarah, cara pencegahan demam berdarah dan cara penanganan pasien yang terkena penyakit demam berdarah. Setelah dilaksanakan penyuluhan kesehatan responden diberikan kesempatan untuk bertanya. Pertanyaan paling banyak adalah tentang tanda dan gejala, cara penularan, cara pencegahan, dan cara penanganan. Umpan balik dari responden yang dicerminkan dengan rasa ingin tahu responden yang sangat tinggi menjadi salah satu alasan peningkatan pengetahuan responden setelah dilakukan penyuluhan.

\section{Sikap}

Rata-rata sikap responden sebelum penyuluhan kesehatan adalah 64,62 dengan sikap sangat baik 161 responden $(70,9 \%)$ tapi setelah penyuluhan dilaksanakan hasil rata-rata sikap mengalami peningkatan menjadi 69,58 dengan sikap sangat baik sebanyak 220 responden $(96,9 \%)$. Setelah responden mendapatkan penyuluhan kesehatan sebagai stimulus, responden mendapatkan tambahan informasi sebagai sumber pengetahuan tentang demam berdarah. Dengan adanya penambahan pengetahuan melalui penyuluhan kesehatan, dapat membuat responden memiliki tambahan informasi sehingga akan mempengaruhi kepercayaan atau keyakinan terhadap suatu objek yaitu demam berdarah ditunjukkan dengan perbaikan sikap yang dapat dilihat dari peningkatan jumlah responden yang memiliki sikap baik.

\section{Tindakan}

Domain perilaku yang terakhir adalah tindakan, ratarata tindakan responden sebelum penyuluhan kesehatan adalah 5,11 dengan tindakan baik sebanyak 17 responden $(7,5 \%)$ tapi setelah penyuluhan dilaksanakan hasil rata-rata tindakan mengalami peningkatan menjadi 5,98 dengan responden yang memiliki tindakan baik sebanyak 40 responden $(17,6 \%)$. Menurut Taufik, ${ }^{9}$ tindakan atau praktik adalah semua aktivitas manusia dalam memelihara kesehatan, setelah responden sadar, tahu, dan mengerti tahap selanjutnya adalah responden tersebut mau melakukan anjuran yang berhubungan dengan kesehatan seperti melakukan perubahan untuk tindakan yang berhubungan dengan pencegahan demam berdarah yang tercermin dalam hasil penelitian pada variabel tindakan.

Tindakan responden meliputi upaya pencegahan demam berdarah seperti menguras dan menyikat tempat penampungan air, menutup rapat tempat penampungan air, mengubur barang bekas, menaburkan bubuk abate, menjaga kondisi rumah agar selalu bersih, menggantung pakaian di lemari, memasang kawat kasa, mengupayakan pencahayaan, membersikan vas yang tergenang air, dan menggunakan kelambu saat tidur. Pada saat kunjungan rumah untuk melakukan observasi terhadap tindakan, ditemukan bahwa sebagian besar keluarga tidak menggunakan bubuk abate. Menurut keterangan dari sebagian responden, mereka mengatakan bahwa mereka tidak menggunakan bubuk abate, mereka berpendapat bahwa cukup dengan menguras bak mandi, mereka bisa terhindar dari demam berdarah. Selain itu, sebagian besar responden juga tidak mengupayakan pencahayaan karena menurut observasi, rumah mereka selalu dalam keadaan tertutup dan gelap. Responden juga sebagian besar tidak menggunakan kelambu saat tidur karena menurut pendapat mereka, jika tidur dengan kelambu mereka merasa kepanasan. Hasil pengamatan setelah penyuluhan kesehatan, sebagian besar rumah responden dalam keadaan bersih, bak mandi dikuras dengan teratur, tempat penampungan air ditutup dengan rapat dan air yang tergenang di belakang pendingin/kulkas serta yang tergenang di dispenser selalu dibuang, barang bekas dibuang dan pakaian tergantung dengan rapi.

\section{Efektifitas Penyuluhan \\ Pengetahuan}

Berdasarkan hasil analisis pengetahuan sebelum dan setelah penyuluhan kesehatan, didapatkan nilai $\mathrm{p}=0,000$ artinya penyuluhan kesehatan tentang demam berdarah efektif karena sangat signifikan terhadap pengetahuan ibu rumah tangga di RW 012 Kelurahan Pondok Kelapa Kecamatan Duren Sawit Jakarta Timur. Penyuluhan bersifat efektif dapat dikarenakan oleh usia responden. Rata-rata usia responden yang mengikuti penyuluhan kesehatan adalah 36-39 tahun, usia tersebut termasuk periode dewasa awal (Early adulthood). Usia tersebut berkisar antara usia $18-40$ tahun. Pada periode ini individu mudah untuk menyerap informasi, serius untuk belajar, berpikir dan memutuskan dengan kehendak sendiri. ${ }^{10}$ Sasaran penyuluhan juga sangat menentukan efektifitas suatu penyuluhan keseahatan, menurut Nasrul Effendy, ${ }^{7}$ faktor-faktor harus diperhatikan di dalam sasaran adalah pendidikan, sosial ekonomi, adat-istiadat, kepercayaan masyarakat dan ketersediaan waktu di masyarakat. Pendidikan terakhir responden yang terbanyak adalah SMA. Pendidikan juga mendukung adanya perubahan pengetahuan yang mengalami peningkatan karena semakin tinggi tingkat pendidikan maka akan semakin mempermudah seseorang untuk menyerap informasi dan secara tidak langsung pengetahuan juga akan meningkat.

\section{Sikap}

Menurut hasil analisis tindakan sebelum dan setelah penyuluhan kesehatan, didapatkan nilai $\mathrm{p}=0,000$ artinya, penyuluhan kesehatan tentang demam berdarah efektif karena sangat signifikan terhadap tindakan ibu 
rumah tangga di RW 012 Kelurahan Pondok Kelapa Kecamatan Duren Sawit Jakarta Timur. Efektifnya penyuluhan kesehatan terhadap tindakan juga tidak lepas dari faktor pendidikan. Dengan pendidikan yang baik, dapat membuat responden memiliki pengetahuan yang baik dan juga sikap yang baik yang kemudian akan dicerminkan dengan tindakan yang baik. Selain dari faktor pendidikan, faktor pekerjaan juga mendukung terjadinya perubahan tindakan. Berdasarkan hasil penelitian menunjukkan bahwa seluruh responden penelitian ini adalah ibu rumah tangga (100\%). Ibu rumah tangga diasumsikan mengetahui keadaan anggota keluarganya dan memiliki perilaku yang mewakili rumah tangganya dalam kaitannya dengan masalah demam berdarah. ${ }^{11}$

Selain daripada itu, alasannya adalah ibu rumah tangga yang memiliki intensitas yang sangat tinggi berada di rumah memiliki peran yang dominan dalam struktur kekuatan keluarga untuk mempengaruhi dan mengendalikan anggota keluarga dengan mengubah perilaku keluarga menjadi perilaku yang mendukung kesehatan. Perubahan tindakan yang sangat terlihat dari masyarakat juga tak lepas dari peran serta aparat pemerintahan seperti Lurah, RW serta RT setempat yang menyediakan petugas untuk memantau jentik (Jumantik). Kegiatan tersebut dilaksanakan dua kali dalam satu bulan setiap hari Jumat pagi. Kegiatan tersebut dilakukan oleh petugas dan didukung oleh masyarakat setempat.

\section{Kesimpulan}

Berdasarkan hasil penelitian pada ibu rumah tangga di RW 012 Kelurahan Pondok Kelapa Kecamatan Duren Sawit Jakarta Timur dapat disimpulkan: (1) Nilai rata-rata dan proporsi pengetahuan, sikap dan tindakan yang baik pada ibu rumah tangga sebelum dan sesudah penyuluhan demam yang meliputi: pengetahuan baik $(14,42$; $30 \%$ menjadi 18,$91 ; 88,1 \%)$, sikap sangat baik $(64,62$ ;70,9\% menjadi 69,58; 96,9\%), tindakan baik $(5,11$; $7,5 \%$ menjadi 5,$98 ; 17,6 \%$ ). (2) Penyuluhan demam berdarah pada ibu rumah tangga berpengaruh secara sangat bermakna terhadap: pengetahuan (nilai $\mathrm{p}=$ 0,000 ); sikap (nilai $\mathrm{p}=0,000$ ) dan tindakan (nilai $\mathrm{p}=$ 0,000 ) pada variabel tindakan, artinya nilai $\mathrm{p}<5 \%$ sehingga dapat disimpulkan bahwa penyuluhan kesehatan tentang demam berdarah efektif karena sangat signifikan terhadap tindakan.

\section{Daftar Pustaka}

1. Mansjoer A. Kapita selekta kedokteran. Jakarta: Media Aesculapius; 2000 .

2. WHO. Demam berdarah dengue: diagnostik, pengobatan, pencegahan dan pengendalian. Edisi 2. Jakarta: EGC; 1999.

3. Subdit Arbovirus Ditjen P2PL Depkes DKI Jakarta; 2007.

4. Suku Kesehatan Masyarakat Jakarta-Timu; 2007.

5. Departemen Kesehatan. Program penanggulangan demam berdarah. Jakarta: EGC; 2007.

6. Nursalam. Konsep dan penerapan metodologi penelitian ilmu keperawatan. Edisi 2. Jakarta: Salemba Medika; 2008.

7. Effendy N. Dasar-dasar keperawatan kesehatan masyarakat. Edisi 2. Jakarta: EGC; 1998.

8. Notoatmodjo S. Promosi kesehatan. Jakarta: Rineka Cipta; 2007.

9. Taufik M. Prinsip-prinip promosi kesehatan dalam bidang keperawatan untuk perawat dan mahasiswa keperawatan. Jakarta: Info Media; 2007.

10. Setiawati S. Proses pembelajaran dalam pendidikan kesehatan. Jakarta: Trans Info Media; 2008.

11. Suprajitno. Asuhan keperawatan keluarga. Jakarta: EGC; 2004. 